\title{
Microbiological Safety of Fruit Juices Consumed in Cafes and Restaurants of Debre-Markos Town, North Western Ethiopia
}

\author{
Kindu Geta ${ }^{* 1}$, Ameha Kebede ${ }^{2}$, Meseret Chemedissa ${ }^{3}$
}

Debre Tabor University, Faculty of Natural and Computational Sciences, Department of Biology, Debre Tabor, Po.box 272, Ethiopia

Haramaya University, Faculty of Natural and Computational Sciences, Department of Biology, Harar, Po.box-138, Ethiopia Haramaya University, Faculty of Natural and Computational Sciences, Department of Biology, Harar, Po.box-138, Ethiopia *Corresponding author: kindu2012@gmail.com

\begin{abstract}
Improperly prepared fresh fruit and vegetable juices are recognized as an emerging cause of food borne illnesses. Therefore, this study was aimed at evaluating the microbiological safety of fresh fruit juices marketed in Debre-Markos town and their hygienic conditions of preparations. Thirty six fruit juices samples were collected from 6 cafés and restaurants of Debre-Markos town and analyzed for total aerobic viable bacterial count (TAVBC), total staphylococcal count (TSC), aerobic spore forming bacterial count (ASFBC), total coliform count (TCC), fecal coliform count (FCC), yeast and mould count (YMC). The spread plate method was used for the isolation of microorganisms on appropriate selective media. All isolates were characterized following standard methods. Bacterial and fungal species were isolated following standard methods. Questionnaires were distributed for 30 juice makers to obtain preliminary information on hygienic and safety practices of fruit juice makers. Results show that the mean TAVBC, ASFBC, TSC, yeast and mold, TCC and FCC of mango were $2.2 \pm 0.48 \times 10^{6}, 0.13 \pm 0.04 \times 10^{5}, 0.004 \times 10^{5}, 1.1 \pm 0.2 \times 10^{6}, 0.15 \pm 0.05 \times 10^{5}, 5.7 \pm 3.73 \times 10^{4}$ and $0.06 \pm 0.04 \times 10^{4} \mathrm{cfu} / \mathrm{ml}$ respectively. The mean of TAVBC, ASFBC, TSC, YMC, TCC, and FCC of avocado juice were $3.6 \pm 0.6 \times 10^{6}, 0.08 \pm 0.02 \times 10^{5}, 0.27 \pm 0.07 \times 10^{5}, 1.2 \pm 0.4 \times 10^{6}$, $0.02 \pm 0.01 \times 10^{5}, 6.46 \pm 3.7 \times 10^{4}$ and $0.2 \pm 0.1 \times 10^{4} \mathrm{cfu} / \mathrm{ml}$ respectively. The bacterial isolates were identified as Staphylococcus aureus, Escherichia coli, Klebsiella spp. Bacillus cereus, Enterobacter spp., Enterococcous spp., Streptococcus spp., and Serratia spp. while the identities of the fungal isolates were Fusarium spp., Mucor spp. and Saccharomyces cerevisiae. The results also showed that the microbial loads of most of the fruit juices were higher than the specifications set for fruit juices sold in the Gulf region and other parts of the world. Most venders obtained fruit from the open market and all juice makers lacked special training in food hygiene and safety. Therefore, regular training and health education on food hygiene and safety is recommended for juice handlers to improve the quality of fresh fruit juices in the study area.
\end{abstract}

KeyWords: fruit juice; debre markos; hygiene; microbial safety. 


\section{INTRODUCTION}

Fruit juice is the unfermented but fermentable natural juice intended for direct consumption obtained by a mechanical process from sound, mature fruits preserved by physical and/or chemical means (Densupsoontorn et al., 2002; FAO/WHO, 2005). They contain large amounts of antioxidants, vitamins C and E, and possess pleasant taste and aroma (Abbo et al., 2006; Shakir et al., 2009). Fresh fruit juices have no artificial color and sweetness is natural that is why they are preferred over bottled or canned juices (Melbourne, 2005; Addo et al., 2008).

Improperly prepared fresh fruits and vegetable juices are recognized as an emerging cause of foodborne illnesses (Sandeep et al., 2004). There have been reports of food borne illnesses associated with the consumption of fruit juices in many countries (Muinde \& Kuria, 2005; Lewis et al., 2006; Chumber et al., 2007; Ghosh et al., 2007). Such juices have been found to be potential sources of bacterial pathogens; notably Escherichia coli 0157:H7, species of Salmonella, Shigella, and Staphylococcus aureus (Sandeep et al., 2004; Barro et al., 2006).

Food-borne or water borne microbial pathogens are leading causes of illnesses in developing countries, killing an estimated 1.9 million people annually at the global level. Even in developed countries, microbiological food-borne diseases affect an estimated one-third of the population each year (Andargie et al., 2008). In Ethiopia, particularly in large urban areas, fruit juices are available in supermarkets in canned or bottled forms. In addition, fruit juice vending houses, which have been serving different types of fruit juices in fresh forms, are proliferating. However, information on the safety of the fruit juices prepared and consumed in Ethiopia is scanty in general (Tsige et al., 2008) and no published information exists on the microbiological safety of the most popular juices, i.e. avocado and mango juices, consumed in Debre- Markos town in particular. It was envisaged that the results generated in the present study would be useful for both the health of consumers and to juice manufacturers to improve microbial safety and hygiene quality. Therefore, this study was aimed at determining the microbiological safety of fruit juices consumed in cafes and restaurants of Debre-Markos town, North Western Ethiopia.

\section{MATERIAL AND METHODS}

\section{Sample Collection and survey}

Thirty-six samples of avocado and mango of locally prepared unpasteurized fruit juices were collected from six cafe or restaurant in Debre-Markos town from Feburary 2014 to May 2014. All the samples were collected on a voluntary basis from participating restaurants and cafes in sterile beakers $(250 \mathrm{ml})$, aseptically labeled, and immediately transported to Debre-Markos University Laboratory in an icebox where they were processed immediately. The questionnaire was used to obtain information on the demographic characteristics of the respondents, sources of fruit, storage conditions, water source for juice preparation as well as for cleaning purpose, cleaning habit of the juice makers, the practice of washing the fruits before making juices, the practice of cleaning the juice processing equipment, whether or not the juice makers have had training in food hygiene and safety, awareness about microbial contamination and its consequences.

\section{Sample Processing and Microbiological Analysis of Fruit Juice}

Microbiological analysis was done using appropriate media designed for enumeration and identification of different microbial groups following standard procedures (Buchanan and Gibbons, 1974). For analysis, $25 \mathrm{ml}$ of fruit juice was measured using measuring cylinder and transferred to $225 \mathrm{ml}$ of sterile peptone water and mixed well in an aseptic environment. The samples were homogenized and appropriate dilutions were plated in duplicates on surfaces of respective media for microbial count using the spread plate technique. Total aerobic viable bacterial (TAVB) were counted on Plate Count Agar (PCA) after incubation at $32{ }^{\circ} \mathrm{C}$ for 48 hours; Spore-forming bacteria were counted on plate count agar after samples were heat treated at $80^{\circ} \mathrm{C}$ for 10 minutes and incubation at $30^{\circ} \mathrm{C}$ for 2 days (Roberts and Greenwood, 2003). Staphylococci were counted on Mannitol Salt agar (MSA) after incubation at 30oC for 48 hours (Mahle et al., 2008). Similarly, Yeasts and molds were counted on Potato dextrose agar plus $0.1 \mathrm{~g}$ streptomycin incubated at $25-28^{\circ} \mathrm{C}$ for 5 days (McLandsborough and Ann, 2005). Smooth (non-hairy) colonies without extension at periphery (margin) were counted as yeasts. Hairy colonies with extension at periphery were counted as molds.

Enterobacteriaceae, coliforms and fecal coliforms were counted using MPN technique. EE medium was used to count Enterobacteriaceae after incubated at $37^{\circ} \mathrm{C}$ for 24 hours and confirmed by streaking samples from positive EE broth culture on Mac Conkey agar medium incubated for $24 \mathrm{~h}$ at $37^{\circ} \mathrm{C}$. Pink to red purple colonies with or without haloes of precipitation were. Brilliant green lactose bile $2 \%$ broth (BGLBB) was used to count coliforms after incubated for $48 \pm 3$ hours at $35 \pm 0.5^{\circ} \mathrm{C}$. Tubes showing positive results were streak plated on eosin methylene blue (EMB) agar and incubated at $37^{\circ} \mathrm{C}$ for $48 \mathrm{hrs}$. EC broth was used to count fecal coliforms after incubated for $48 \pm 3$ 
hours at $45 \pm 0.5^{\circ} \mathrm{C}$ in water bath and confirmed by streaking from positive EC broth culture on eosin methylene blue agar (EMB) plates after incubation for 48 hours at $37^{\circ} \mathrm{C}$ (Farzana et al., 2009). Purplish red colonies surrounded by reddish zone of precipitated bile were counted as coliforms. After enumeration, five colonies were randomly picked from countable plates of PCA, MSA, PDA, MacConkey, and EMB agar plates and further purified by repeated plating on PCA. The resulting bacterial isolates were then identified following standard microbiological procedures as described by Buchanan and Gibbons (1974) and Cheesbrough (2002), while the fungal isolates were identified based on the taxonomic schemes and descriptions provided by Ainsworth et al. (1973) and Mislivec et al. (1992).

Data analysis was done using the SPSS computer software version 20.0. ANOVA was used to compare mean values among sampled juices. P-values less than $0.05(P \leq 0.05)$ were considered statistically significant.

\section{RESULTS AND DISCUSSION}

Among 30 juice makers more than half (56.7\%) of the fruit juice makers who participated in this study were females and 26 (86.7\%) of them were younger than 35 years of age. $73.3 \%$ had education higher than primary education; $16.7 \%$ had primary education while only 10 $\%$ had non-formal education (Table 1). The source of fruits used for the processing of juices was primarily from the open market (83.3\%) while some juice makers $(16.7 \%)$ got their fruits directly from producers who were their routine suppliers. Fruit juice producers made use of both ripened and over-ripened fruits but with preference to ripened fruits as this constituted $83.3 \%$ of the cases. The temporary storage sites of fruits were shelves (50\%), baskets (33.3\%), and refrigerators $(16.7 \%)$. Moreover, none of the fruit juice makers was practicing using of antiseptics to washing fruits required in the preparation of fruit juices. All of the venders were using tap water for dilution of fruit juices and washing fruits before making juices with water only. All juice producers lacked special training in food hygiene and safety as it is indicated in this study and some $(26.7 \%)$ had the awareness on the consequences of consuming contaminated foods (Table 2 ).

Table 1: Demographic characteristics of respondents in Debre Markos town

\begin{tabular}{lllllllll} 
& M & 6.7 & 10 & 13.3 & 6.7 & 3.3 & 3.3 & 43.3 \\
Age & $16-35$ & 13.3 & 16.7 & 16.7 & 13.3 & 13.3 & 13.3 & 86.7 \\
\multirow{3}{*}{ Education status of juice makers } & $>35$ & 3.3 & 0 & 3.3 & 3.3 & 3.3 & 0 & 13.3 \\
& Non formal & 3.3 & 0 & 3.3 & 3.3 & 0 & 3.3 & 13.3 \\
& Elementary & 0 & 6.7 & 3.3 & 0 & 3.3 & 0 & 13.3 \\
& High school & 16.7 & 16.7 & 20 & 16.7 & 16.7 & 13.3 & 73.3 \\
\hline
\end{tabular}

Key: $A, B, C, D, E$ and $F$ stand for the house where samples were collected.

Table 2: Respondents' level of awareness towards microbial contaminants, food safety as well as the hygienic conditions of the fruit juice processing in Debre Markos town 
Variables

Percent of respondents in Café and restaurants

Awareness of juice makers about microbes presence as contaminants on fruit/fruit juice

Awareness of juice makers about diseases resulting from contaminated food

Source of fruit

Nature of fruit

Temporary storage of fruit

Cleaning habit of juice makers during juice preparation

Training in food hygiene and safety

Water source for juice preparation

\begin{tabular}{lllllll}
\hline A & B & C & D & E & F & Total
\end{tabular}

\begin{tabular}{|c|c|c|c|c|c|c|c|}
\hline Yes & 10 & 13.3 & 16.7 & 13.3 & 16.7 & 10 & 80 \\
\hline No & 6.7 & 3.3 & 3.3 & 3.3 & 0 & 3.3 & 20 \\
\hline Yes & 3.3 & 3.3 & 3.3 & 6.7 & 6.7 & 3.3 & 26.7 \\
\hline No & 13.3 & 13.3 & 16.7 & 10 & 10 & 10 & 73.3 \\
\hline Market & 16.7 & 16.7 & 20 & 0 & 16.7 & 13.3 & 83.3 \\
\hline Producers & 0 & 0 & 0 & 16.7 & 0 & 0 & 16.7 \\
\hline Ripened & 0 & 16.7 & 20 & 16.7 & 16.7 & 13.3 & 83.3 \\
\hline Over ripened & 16.7 & 0 & 0 & 0 & 0 & 0 & 16.7 \\
\hline Shelf & 16.7 & 16.7 & 0 & 16.7 & 0 & 0 & 50 \\
\hline Basket & 0 & 0 & 20 & 0 & 0 & 13.3 & 33.3 \\
\hline Refrigerator & 0 & 0 & 0 & 0 & 16.7 & 0 & 16.7 \\
\hline With water & 16.7 & 0 & 0 & 0 & 0 & 0 & 16.7 \\
\hline Water + soap & 0 & 16.7 & 20 & 0 & 0 & 13.3 & 50 \\
\hline $\begin{array}{l}\text { Water +soap } \\
+ \text { Antiseptic }\end{array}$ & 0 & 0 & 0 & 16.7 & 16.7 & 0 & 33.3 \\
\hline Yes & 0 & 0 & 0 & 0 & 0 & 0 & 0 \\
\hline No & 16.67 & 16.67 & 20 & 16.67 & 16.67 & 13.3 & 100 \\
\hline Tap & 16.7 & 16.7 & 20 & 16.7 & 16.7 & 13.3 & 100 \\
\hline Well & 0 & 0 & 0 & 0 & 0 & 0 & 0 \\
\hline Spring & 0 & 0 & 0 & 0 & 0 & 0 & 0 \\
\hline
\end{tabular}

Key: $A, B, C, D, E$ and $F$ stand for the house where samples were collected.

The data revealed that both fruit juice samples collected from all houses were contaminated with heavy load of total aerobic viable bacteria. The overall mean total aerobic viable bacterial count was $2.9 \pm 0.4 \times 10^{6} \mathrm{cfu} / \mathrm{ml}$. The mean total aerobic viable bacterial count of avocado juice $\left(3.6 \pm 0.6 \times 10^{6} \mathrm{cfu} / \mathrm{ml}\right)$ was higher than that of mango juice $\left(2.2 \pm 0.48 \times 10^{6} \mathrm{cfu} / \mathrm{ml}\right)$. The mean total aerobic viable bacterial counts did not show statistically significant difference between avocado and mango fruit juices $(P \leq 0.05)$ (Table 3). Higher levels of TAVBC in fresh fruits also reflect poor agricultural practices and hygiene codes like post harvest washing with contaminated water (Stannard, 1997). The results of the present study showed that all of the fruit juice samples showed much higher viable bacterial counts than the permitted counts. The specifications for fruit juices served in the Gulf region recommend that the maximum count permitted for total aerobic bacterial count coliforms, yeast and mould should be $5 \times 10^{4}, 100$, and $1.0 \times 10^{3} \mathrm{cfu} / \mathrm{ml}$, respectively (Gulf Standards, 2000).

Rahman et al. (2011) reported that the total viable bacterial count in most of the fresh juice samples was higher than the commercially packed juice samples, as the highest counts they obtained for fresh and packed juice samples were $2.4 \times 10^{4} \mathrm{cfu} / \mathrm{ml}$ and $3.2 \times 10^{3} \mathrm{cfu} / \mathrm{ml}$, respectively, which were found to be lower than the results of the present study. Al-Jedah and Robinson (2002) reported total viable bacterial counts of $4.9 \times 10^{6} \mathrm{cfu} / \mathrm{ml}$ and $1.3 \times 10^{5} \mathrm{cfu} / \mathrm{ml}$ for avocado and mango juice samples respectively. From their finding total bacterial count of avocado juice sample was higher than this study and total bacteria count of mango was lower than this study. Shakir et al. (2009) also reported that the total aerobic bacteria count of $8.00 \times 10^{3}-8.05 \times 10^{8} \mathrm{cfu} / \mathrm{ml}$ for mango juices and the mean total viable count (microbial load) showed the presence of bacteria in all the freshly prepared fruit juices in the range from $3.00 \times 10^{2}$ to $9.60 \times 10^{8} \mathrm{cfu} / \mathrm{ml}$. Total bacteria 
count of mango juice sample of this study was lower than the finding of the author. Tsige et al. (2008) also reported that the mean aerobic mesophilic bacteria counts (cfu/ml) of avocado, papaya and pine-apples were $8.0 \times 10^{6}, 3.1 \times 10^{7}$, and $7.9 \times 10^{6} \mathrm{cfu} / \mathrm{ml}$, respectively. The difference in colonial count between the studies may attribute to different factors such as geographical variation, $\mathrm{pH}$, seasonal variation, hygiene, incubation time, sample transportation time, handling and processing, and storage.

The mean aerobic spore former bacteria counts ranges from $0.08 \pm 0.02 \times 10^{5} \mathrm{cfu} / \mathrm{ml}$, as in the case of avocado, to $0.13 \pm 0.04 \times 10^{5} \mathrm{cfu} / \mathrm{ml}$ in mango juice. The overall mean total Staphylococcal count was $0.14 \pm 0.03 \times 10^{5} \mathrm{cfu} / \mathrm{ml}$ with the maximum and minimum mean counts being $0.27 \pm 0.07 \times 10^{5} \mathrm{cfu} / \mathrm{ml}$ (from avocado) and $0.004 \times 10^{5} \mathrm{cfu} / \mathrm{ml}$ (from mango), respectively. Among the type of juice, avocado was show high number of staphylococcal species. The mean yeast counts ranges from $1.1 \pm 0.2 \times 10^{6} \mathrm{cfu} / \mathrm{ml}$, as in the case of mango juice to $1.2 \pm 0.4 \times 10^{6}$ $c f u / m l$ in avocado juice (Table 3). According to study conducted in Nigeria, the highest number of Staphylococcus species $\left(3.5 \times 10^{4} \mathrm{cfu} / \mathrm{ml}\right)$ was observed in avocado juices (Bello et al., 2014). Even though the type of juices to show high number of Staphylococcus species was similar in both study, the magnitude of Staphylococcus species was relatively less in this study $\left(0.27 \pm 0.07 \times 10^{5}\right)$. The mean yeast counts ranged from $1.1 \pm 0.2 \times 10^{6} \mathrm{cfu} / \mathrm{ml}$ (in mango juice) to $1.2 \pm 0.4 \times 10^{6} \mathrm{cfu} / \mathrm{ml}$ (in avocado juice). On the other hand, the overall mean total count of moulds was $0.08 \pm 0.02 \times 10^{5} \mathrm{cfu} / \mathrm{ml}$. Both fruit juices were highly contaminated with yeast next to total aerobic bacteria compared with other organisms. Avocado juices was recorded the lower mold count $\left(0.02 \pm 0.01 \times 10^{5} \mathrm{cfu} / \mathrm{ml}\right)$ than mango juice $\left(0.15 \pm 0.05 \times 10^{5} \mathrm{cfu} / \mathrm{ml}\right)$. Yeast count of avocado juice recorded in this study was higher than yeast count $\left(3 \times 10^{4} \mathrm{cfu} / \mathrm{ml}\right)$ reported in the work of Bello et al., (2014), and mold counts was relatively lower $\left(4 \times 10^{4} \mathrm{cfu} / \mathrm{ml}\right)$ than the author.

The mean total Enterobacteriaceae, coliform and fecal coliform counts were $7.85 \pm 2.8 \times 10^{4}, 6.08 \pm 2.5 \times 10^{4}$ and $0.13 \pm 0.06 \times 10^{4} \mathrm{cfu} / \mathrm{ml}$, respectively. The mean total Entrobacteriaceae, coliform and fecal coliform counts were $12.15 \pm 4.8 \times 10^{4}, 6.46 \pm 3.7 \times 10^{4}$ and $0.2 \pm 0.1 \times 10^{4} \mathrm{cfu}$ $/ \mathrm{ml}$ for avocado juice and $3.56 \pm 2.7 \times 10^{4}, 5.7 \pm 3.73 \times 10^{4}$ and $0.06 \pm 0.04 \times 10^{4} \mathrm{cfu} / \mathrm{ml}$ for mango juice, respectively. Generally, these counts did not show statistically significant difference between juice types $(P \leq 0.05)$ (Table 4$)$. Most of the fruit juices in this study were found to be unfavorable for consumption because many of them showed the presence of Entrobacteriaceae, coliform and fecal coliforms. The presence of coliform in fruit juice is not allowed by safe food consumption standard (Andres et al., 2004). Total coliform count of this study was higher than the work of Lewis et al., (2006) who reported that coliforms counts varied between $0.8-22.2 \times 10^{4} \mathrm{cfus} / 100 \mathrm{ml}$. All over, total aerobic viable bacteria, yeast and aerobic spore former bacteria,coliform and faecal coliform counts between avocado and mango juice collected from different cafes and restaurants did not show statistically significant difference, where as Entrobacteriaceae, Staphylococci and mold count were significantly different. Several food safety reports published to highlight the safety status of street vended fruits, vegetables and their juices associate consumer health threats with unhygienic environment, poor juice extraction and handling practices, extremely low grade raw material and the general health of the vendors (Lewis et al., 2006; Tambekar et al., 2009; Titarmare et al., 2009). Based on morphological and biochemical test eight bacterial genera were isolated from the fruit juices and these were characterized as Staphylococcus aureus, E. coli, Klebsiella spp, Bacillus cereus, Enterobacter spp, Streptococcus spp, Entrococcus spp and Serratia spp. Three fungal genera were also isolated from the fruit juices based on cultural and microscopic characterization and these were characterized as Saccharomyce cervicea, mucor spp and Fusarium spp. (Table 5). This result was in line with the study of Bello et al, 2014 who reported that Klebsiella spp., Enterobacter spp., Bacillus cereus, Serratia sp., Staphylococcus aureus, Penicillium spp. and Aspergillus niger were isolated from avocado juice. Another study conducted in India showed that pathogenic E. coli was seen in 27.7\%, Shigella in 16.6\%, Salmonella in $38.8 \%$ and S. faecalis in $6.2 \%$ of the samples (Lewis et al, 2006).

Table 3: Microbial counts of fresh fruit (mango and avocado) juices sold in Debre-Markos town. 


\begin{tabular}{|c|c|c|c|c|c|}
\hline $\begin{array}{l}\text { Sample } \\
\text { Area }\end{array}$ & $\begin{array}{l}\text { TAVBC } \\
\left(\mathrm{x} 10^{6}\right)\end{array}$ & $\begin{array}{l}\text { TSFBC } \\
\left(\mathrm{x} 10^{5}\right) \\
\end{array}$ & $\begin{array}{l}\mathrm{SC} \\
\left(\mathrm{x} 10^{5}\right) \\
\end{array}$ & $\begin{array}{l}\mathrm{YC} \\
\left(\mathrm{x} 10^{6}\right) \\
\end{array}$ & $\begin{array}{l}\mathrm{MC} \\
\left(\mathrm{x} 10^{5}\right) \\
\end{array}$ \\
\hline MA & $2.3 \pm 0.9^{\mathrm{abc}}$ & $0.25 \pm 0.24^{\mathrm{a}}$ & $0.02 \pm 0.01^{\mathrm{a}}$ & $0.8 \pm 0.2^{\mathrm{ab}}$ & $0.42 \pm 0.21^{\mathrm{a}}$ \\
\hline MB & $0.6 \pm 0.2^{\mathrm{c}}$ & $0.1 \pm 0.06^{\mathrm{a}}$ & 0 & $1.6 \pm 0.6^{\mathrm{ab}}$ & $0.1 \pm 0.08^{\mathrm{ab}}$ \\
\hline $\mathrm{MC}$ & $3.8 \pm 1.1^{\mathrm{ab}}$ & $0.2 \pm 0.09^{\mathrm{a}}$ & 0 & $0.6 \pm 0.2^{\mathrm{b}}$ & $0.22 \pm 0.16^{\mathrm{ab}}$ \\
\hline MD & $4.6 \pm 1.7^{\mathrm{a}}$ & $0.16 \pm 0.1^{\mathrm{a}}$ & 0 & $1.9 \pm 0.8^{\mathrm{a}}$ & $0.01 \pm 0.00^{\mathrm{b}}$ \\
\hline $\mathrm{ME}$ & $0.74 \pm 0.36^{\mathrm{bc}}$ & $0.02 \pm 0.01^{\mathrm{a}}$ & 0 & $0.7 \pm 0.3^{\mathrm{ab}}$ & $0.01 \pm 0.01^{\mathrm{b}}$ \\
\hline MF & $1.3 \pm 0.8^{\mathrm{bc}}$ & $0.06 \pm 0.03^{\mathrm{a}}$ & 0 & $0.8 \pm 0.3^{\mathrm{ab}}$ & $0.12 \pm 0.08^{\mathrm{ab}}$ \\
\hline Total mean & $2.2 \pm 0.48$ & $0.13 \pm 0.04$ & 0.004 & $1.1 \pm 0.2$ & $0.15 \pm 0.05$ \\
\hline AA & $7.8 \pm 1.9^{\mathrm{a}}$ & $0.15 \pm 0.08^{\mathrm{ab}}$ & $0.11 \pm 0.06^{\mathrm{b}}$ & $2.7 \pm 1.3^{\mathrm{ab}}$ & $0.12 \pm 0.05^{\mathrm{a}}$ \\
\hline $\mathrm{AB}$ & $0.6 \pm 0.2^{\mathrm{b}}$ & $0.04 \pm 0.03^{\mathrm{ab}}$ & $0.04 \pm 0.02^{\mathrm{b}}$ & $0.09 \pm 0.04^{\mathrm{b}}$ & $0.02 \pm 0.01^{\mathrm{b}}$ \\
\hline $\mathrm{AC}$ & $8.9 \pm 2.4^{\mathrm{a}}$ & $0.23 \pm 0.13^{\mathrm{a}}$ & $0.02 \pm 0.01^{\mathrm{b}}$ & $3.2 \pm 1.9^{\mathrm{a}}$ & 0 \\
\hline $\mathrm{AD}$ & $0.5 \pm 0.3^{\mathrm{b}}$ & $0.05 \pm 0.04^{\mathrm{ab}}$ & 0 & $0.28 \pm 0.15^{\mathrm{b}}$ & 0 \\
\hline $\mathrm{AE}$ & $1.2 \pm 0.3^{\mathrm{b}}$ & 0 & $0.23 \pm 0.08^{b}$ & $0.2 \pm 0.07^{\mathrm{b}}$ & 0 \\
\hline $\mathrm{AF}$ & $2.7 \pm 0.5^{\mathrm{b}}$ & $0.01^{\mathrm{b}}$ & $1.21 \pm 0.3^{\mathrm{a}}$ & $0.7 \pm 0.2^{\mathrm{ab}}$ & 0 \\
\hline Total mean & $3.6 \pm 0.6$ & $0.08 \pm 0.02$ & $0.27 \pm 0.07$ & $1.2 \pm 0.4$ & $0.02 \pm 0.01$ \\
\hline
\end{tabular}

Data represent mean \pm standard error of 3 samples ( $3 \times 4$ replications), $a, b, c, d=$ Mean within column with the same letter for same count are not significantly different $(P \leq 0.05)$

Key: $M=$ mango, $1^{\text {st }} A=$ avocado, $2^{\text {nd }} A, B, C, D, E$ and $F$ stand for the $1^{\text {st }}, 2^{\text {nd }}, 3^{\text {rd }}, 4^{\text {th }}, 5^{\text {th }}$ and $6^{\text {th }}$ house where samples were collected.

$T A V B C=$ total aerobic viable bacterial count, $S C=$ staphylococcal count, $A S F B C=$ aerobic spore forming bacterial count, YC=yeast count and $M C=$ mould count .

Table 4: Total Entrobacteriaceae, Total Coliform and Total Fecal Coliform Count (x10 $\left.0^{4} \mathrm{cfus} / \mathrm{ml}\right)$ of fresh fruit (mango and avocado) juices sold in Debre Markos town. 


\begin{tabular}{llll}
\hline Sample area & Entrobacteriaceae & TCC & FCC \\
\hline MA & $1.02 \pm 0.8^{\mathrm{a}}$ & $0.15 \pm 0.08^{\mathrm{b}}$ & $0.1 \pm 0.1^{\mathrm{a}}$ \\
MB & $0.69 \pm 0.6^{\mathrm{a}}$ & $0.06 \pm 0.06^{\mathrm{b}}$ & 0 \\
MC & $17.07 \pm 16.1^{\mathrm{a}}$ & $32.86 \pm 16.3^{\mathrm{a}}$ & $0.25 \pm 0.25^{\mathrm{a}}$ \\
MD & $0.3 \pm 0.2^{\mathrm{a}}$ & $0.17 \pm 0.14^{\mathrm{b}}$ & 0 \\
ME & $0.46 \pm 0.27^{\mathrm{a}}$ & $0.22 \pm 0.13^{\mathrm{b}}$ & 0 \\
MF & $1.79 \pm 0.56^{\mathrm{a}}$ & $0.72 \pm 0.58^{\mathrm{b}}$ & $0.02 \pm 0.01^{\mathrm{a}}$ \\
Total mean & $\mathbf{3 . 5 6} \pm \mathbf{2 . 7}$ & $\mathbf{5 . 7} \pm \mathbf{3 . 7 3}$ & $\mathbf{0 . 0 6} \pm \mathbf{0 . 0 4}$ \\
AA & $34.3 \pm 14.96^{\mathrm{a}}$ & $19.34 \pm 14.96^{\mathrm{a}}$ & $0.54 \pm 0.13^{\mathrm{a}}$ \\
AB & $0.98 \pm 0.86^{\mathrm{b}}$ & $0.94 \pm 0.03^{\mathrm{a}}$ & 0 \\
AC & $32.85 \pm 16.41^{\mathrm{a}}$ & $17.89 \pm 15.73^{\mathrm{a}}$ & $0.03 \pm 0.03^{\mathrm{a}}$ \\
AD & $0.2 \pm 0.09^{\mathrm{b}}$ & $0.3 \pm 0.03^{\mathrm{a}}$ & 0 \\
AE & $0.17 \pm 0.1^{\mathrm{b}}$ & $0.06 \pm 0.03^{\mathrm{a}}$ & 0 \\
AF & $4.38^{\mathrm{b}}$ & $1.37 \pm 0.7^{\mathrm{a}}$ & $0.67 \pm 0.6^{\mathrm{a}}$ \\
Total mean & $\mathbf{1 2 . 1 5} \pm \mathbf{4 . 8}$ & $\mathbf{6 . 4 6} \pm \mathbf{3 . 7}$ & $\mathbf{0 . 2} \pm \mathbf{0 . 1}$ \\
\hline
\end{tabular}

Data represent mean \pm standard error of 3 samples, a, b, c, d= Mean within column with the same letter for same count are not significantly different $(\mathrm{P} \leq 0.05)$.

Table 5: Frequency of occurrence of bacterial and fungal isolates from avocado and mango fruit juice collected from Debere Markos town $(\mathrm{n}=40)$

Avocado Juice Mango Juice

Isolate

\begin{tabular}{|c|c|c|c|c|}
\hline & Frequency & $\%$ & Frequency & $\%$ \\
\hline S. aureus & 5 & 12.5 & 1 & 2.5 \\
\hline E. coli & 3 & 7.5 & 1 & 2.5 \\
\hline Klebsiella sp & 2 & 5 & 1 & 2.5 \\
\hline B. cereus & 1 & 2.5 & 1 & 2.5 \\
\hline Enterobacter sp & 3 & 7.5 & 1 & 2.5 \\
\hline Streptococcus sp & 1 & 2.5 & 2 & 5 \\
\hline Enterococcus sp & 2 & 5 & 3 & 7.5 \\
\hline Serratia sp. & 1 & 2.5 & 1 & 2.5 \\
\hline S. cerevisiae & 2 & 5 & 4 & 10 \\
\hline Mucor sp & 0 & 0 & 2 & 5 \\
\hline Fusarium sp. & 1 & 2.5 & 2 & 5 \\
\hline Total & 21 & 52.5 & 19 & 47.5 \\
\hline
\end{tabular}

\section{CONCLUSIONS}

Generally, the results in the present study clearly indicate the poor hygienic conditions of these juices and the consumers are at risk of contacting food borne infections. The fruit juices investigated in this study had higher microbial load than the specifications set for fruit juices in some parts of the world. These high counts, however, may pose hazard to the health of consumers especially if pathogenic species are present in the fruit juices to be consumed. Government Health Agencies must adopt measures to educate the vendors on food safety and hygienic practices and enforce adequate guidelines for street food vending.

\section{Acknowledgements}


I am thankful to Haramaya University School of Graduate Studies for providing me with financial support to conduct this project. I would like to thank Debre Markos University for their willingness to allow me to use the laboratory for conducting my experiments. My heartfelt thanks go to anonymous reviewers for their critical and constructive comment.

\section{REFERENCES}

1. Abbo ES, Olurin T, Odeyemi G. (2006). Studies on the storage stability of soursop (Annona muricata L.) juice. Afr. J. Biotechnol. 5:108-112.

2. Addo M.G, Akanwariwiak WG, Addo-pordjour P, Obiri-Danso K. (2008). Microbiological and sensory analysis of imported fruit juices in Kumasi, Ghana. Res. F. Microbio, 3: 522-528.

3. Ainsworth GC, Sparrow FK, Sussman AS. (1973). The Fungi Vol.1 VA: A Taxonomic Review with keys; Ascomycetes and Fungi imperfecti, London: Academic Press. pp. 13-67.

4. Al-jedah JH and Robinson RK. (2001). Nutritional value and microbiological safety of fresh fruit juices sold through retail outlets in Qatar. Pakistan. J Nutr.1:79-81.

5. Andargie G, Kassu A, Moges F, Tiruneh M, and Huruy K. (2008). Prevalence of Bacteria and Intestinal Parasites among Foodhandlers in Gondar Town, Northwest Ethiopia. J Health Popul Nutr. 26:451-455.

6. Barro N, Bello AR, Aly S, Ouattara CAT, Ilboudo AJ, Traoré AS. (2006). Hygienic status and assessment of dishwashing waters, utensils, hands, and pieces of money from street food processing sites in Ouagadougou (Burkina Faso). Afr.J.Biotechnol. 5 (11): 1107-1112.

7. Bello Olorunjuwon O., Bello Temitope K., Fashola Muibat O., Oluwadun Afolabi (2014). Microbiological quality of some locally produced fruit juices in Ogun State, Southwestern Nigeria. J. Microbiolo. 2(1): 001-008.

8. Buchanan RE, Gibbons NE. (1974). Bergey's Manual of Determinative Bacteriology, Baltimore. Williams and Wilkins Co. 8th edn. pp. 34-89.

9. Cheesbrough M. (2002). Biochemical Tests to Identify Bacteria. In: Laboratory Practice in Tropical Countries, Cheesbrough M (Eds). Cambridge edn. pp. 63-70.

10. Chumber SK, Kaushik K, Savy S. (2007). Bacteriological analysis of street foods in Pune, Indian. J. Public Health. 51(2): 114-6.

11. Densupsoontorn, N., P. Jirapinyo, N. Thomonsiri, R. Wong, P. Rhosuya, A. Tritipat, S. Pattrarat, P. Pidatcha and L. Suwannthol, (2002). Comparison of the Nutrient Content of fresh fruit juices vs commercial fruit juices. J. the Medical Association of Thailand. 2: $732-738$.

12. FAO/WHO. (2005). Codex general standard for fruit juices and nectars CODEXSTAN 247-2005.

13. Farzana, K., S. AK htar, and F. Jabeen. (2009). Prevalence and antibiotic resistance of some bacteria in two ethnic milk based products. Pak. J. Bot. 41:935-943.

14. Ghosh M, Wahi S, Ganguli MB. (2007). Prevalence of enterotoxigenic Staphylococcus aureus and Shigella spp. in some raw street vended Indian foods. Int. J. Environ. Health. Res. 17(2): 151-156.

15. Gulf Standards. (2000). Microbiological criteria for food stuffs-part 1. GCC, Riyadh, Saudi Arabia. p. 7-20

16. Lewis Joy E, Thompson P, Rao B, Kalavati, C, Rajanna B. (2006). Human Bacteria in Street scale fruit juice processing. A Case Study of Visakhapatnam City, India: Int. J.Food Safety, 8, 35-38.

17. Mahale D P, Khade RG, Vaidya VK. (2008). Microbiological Analysis of Street Vended Fruit Juices from Mumbai City, India. Int.J.Food Safety, 10:31-34.

18. McLandsborough\&Ann. (2005). Food Microbiology Laboratory CRC Series in Contemborary Food Science.Boca Raton London New York Washington, D.C.3:27-28.

19. Mislivec PB, Beuchat LR, Cousin MA. (1992). Yeasts and molds In: Compendium of methods for the microbiolocal examination of foods. Vanderzant C, Splittstoesser DF (Eds). American Public Health Association, Washington, DC.

20. Muinde OK. and Kuria E. (2005). Hygienic and sanitary practices of vendors of street foods in Nairobi, Kenya. AJFAND online www.ajfand.net. $5(1): 1-13$.

21. Rahman T, Hasan S, Noor R. (2011). An Assessment of Microbiological Quality of Some Commercially Packed and Fresh Fruit Juices available in Dhaka City: A Comprehensive Study. Stanford J. Microbiol. 1(1):13-18

22. Roberts D and Greenwood M. (2003). Practical Food Microbiology, Third Edition, USA, Blackwell Publishing Inc.

23. Sandeep M, Diwakar A, Abhijit G. (2004). Microbiological Analysis of Street Vended Fresh squeezed Carrot and Kinnow-Manderian Juices in Patiala City, India. Internet J. Food safety. 3:1-3. 
24. Shakir M, Ahmed U, Nasreen T, Feroza B and Parveen S. (2009). Microbiological Quality of Local Market Vended Freshly Squeezed Fruit Juices in Dhaka City, Bangladesh. Bangladesh J. Sci. Ind. Res. 44: 421-424.

25. Stannard, C. (1997). Development and use of microbiological criteria for foods. Food Sci. Technol. Today 11:137-176.

26. Tambekar, D.H., S.D. Shirsat, S.B.Suradkar, P.N. Rajankar, and Y.S. Banginwar. (2007). Prevention of transmission of infectious disease: Studies on hand hygiene in health-care among students. Continental J. Biomedical Sciences. 1: 6-10.

27. Titarmare, A., P. Dabholkar and S. Godbole. (2009). Bacteriological analysis of street vended fresh fruit and vegetable juices in Nagpur city, India. Internet J. Food Safety 11:1-3.

28. Tsige K, Tsegaye G, Ketema B. (2008). Microbiological Safety Of Fruit Juices Served In Cafes/Resturants, Jimma Town, Southwest Ethiopia. Ethiop J Health Sci. 18(3).97-99 